\title{
Benchmark Revisions of the Money Stock and Ranges of Money Stock Growth
}

\author{
RICHARD W. LANG
}

$W_{\mathrm{E}}$ 1973 have been revised usually three or four times each year by the Board of Govemors of the Federal Reserve System. These frequent revisions are made to incorporate "benchmark" adjustments to the components of the weekly monetary aggregates that are estimated for banks which are not members of the Federal Reserve System.

Data on deposits and vault cash for these nonmember banks are available only for a few dates each year and weekly data between these dates must be estimated. Initial estimates of nonmember bank deposits and vault cash are subsequently revised as more infor. mation becomes available, in order to "benchmark" the estimated weekly data to the few weeks of actual nonmember bank data. ${ }^{1}$

The most recent benchmark revision of the monetary aggregates was made on March 23, 1978. Due to longer than usual delays in processing reports from nonmember banks, this revision incorporated nonmember bank data from four, rather than from one or two, reporting periods. This revision resulted in a $\$ 1.3$ billion increase in the narrowly-defined money stock (M1) at the end of 1977 - a figure which appears to be quite large. The change in the level of the money stock resulted, however, in less than a one-half percentage point change in the growth rate of M1 during 1977 .

This article explains how benchmark revisions of money stock data are made and examines their effects on rates of money growth relative to the Federal Reserve's ranges. Benchmark revisions generally have resulted in relatively small changes in either short- or

\footnotetext{
Since monthly data is constructed from weekly data, these revisions affect monthly data as well. Weekly deposit data for nonmember banks around call report dates have been available only since March 1976. Prior to that date, single-day call report data was used.

'As this article was going into print, another benchmark revision was announced on June 22, 1978.
}

long-run rates of money growth compared with the ranges set by Federal Reserve policymakers. Whether or not benchmark revisions would have a more significant effect on money growth rates in the event that bank membership in the Federal Reserve System continues to decline remains an open question.

\section{NONMEMBER PANKS AND MONEY STOCK DATA}

Although the basic definition of the narrowlydefined money stock (M1) seems quite straightor " ward - MI is the sum of private demand deposits at all commercial banks plus currency and coin held by the nonbank public - the actual construction of weekly M1 data is more complicated. As shown in Table I, not only are a number of adjustments made to obtain the currency and demand deposit components of M1, but a number of these items must be estimated as well. Two of the estimated items important to the construction of MI are demand deposits and vault cash of nonmember banks. These items must be estimated to obtain a weekly series on M1 since actual nonmember bank data on deposits and vault cash are only avallable for, at most, four weeks each year.

Banks which are members of the Federal Reserve System make weekly reports of selected assets and liabilities to the Federal Reserve Bank in their district in order for the Federal Reserve to verify their holdings of required reserves. These balance sheet data are used to construct the member bank items which are included in the money stock (Table 1). Although member banks make up less than hall of the about 14,700 commercial banks in the United States (Table II), they hold about 73 percent of the total deposits in the banking system (Table III). Consequently, member bank data comprise the largest portion of the weekly MI numbers,

Banks which do not belong to the Federal Reserve System must meet reserve requirements of the various 


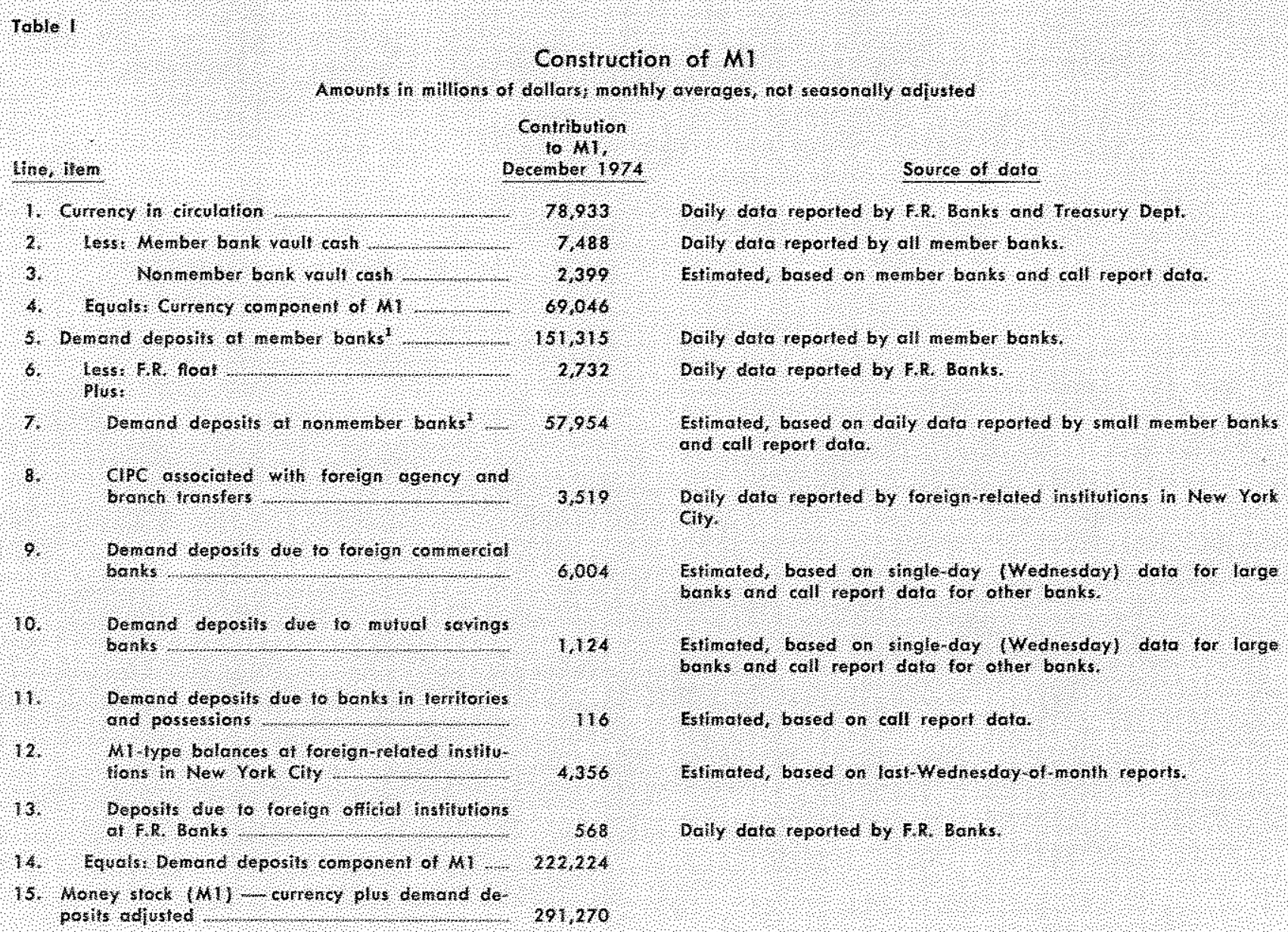

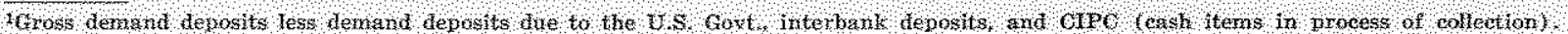

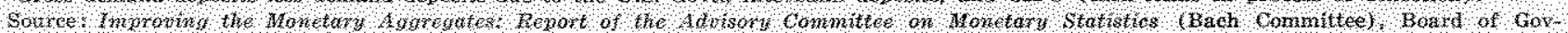

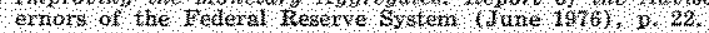

state banking authorities, and generally file extensive reports on their assets and liabilities only on a few dates each year. ${ }^{2}$ For example, nonmember banks insured by the Federal Deposit Insurance Corporation (FDIC) are required to file Reports of Condition (call reports) with the FDIC four times each year. Call reports are filed at the end of March, June, September; and December. Balance sheet data from these call reports are forwarded to the Federal Reserve by the FDIC, usually after a delay, and are then used in the construction of M1."

2 For a listing of state reserve recuirements and their reporting periods, see R. Alton Gilbert and Jean M. Lovati, "Bank Reserve Requirements and Their Enforcement: A Comparison Across States," this Retiew (March 1978), pp, 22-32. The reports discussed by Gilbert and Lovati are not geterally "Reports of Condition" such as are filed by insured banks with the FDIC.

" Improving the Monetary Aggregates: Report of the Advisory Committee on Monetary Statistics" (Bach Committee), Board of Governors of the Federal Reserve System (June 1976), p. 29. Prior to 1973 , only the June and December call reports
Nonmember banks which are not insured by the FDIC (noninsured nonmember banks) file Reports of

Table ll

\section{Number of Commercial Banks}

\begin{tabular}{|c|c|c|c|c|}
\hline \multirow[b]{2}{*}{$\begin{array}{l}\text { End ol Perbod } \\
\text { December } 31\end{array}$} & \multirow[b]{2}{*}{$\begin{array}{l}\text { Member } \\
\text { Botuks }\end{array}$} & \multicolumn{3}{|c|}{ Nonmember Eonks } \\
\hline & & lotol & Fold & None \\
\hline 1960 & 0174 & 7300 & 6948 & 352 \\
\hline 1965 & 6221 & 7583 & 7320 & 263 \\
\hline 1970 & 5767 & 7919 & 7735 & 184 \\
\hline 1975 & 5787 & 8846 & 8585 & 261 \\
\hline 1976 & 5758 & 8914 & 8699 & 275 \\
\hline $1977^{1}$ & 5720 & 8998 & 8705 & 293 \\
\hline
\end{tabular}

TCal repont on bune 30,197

Sotnet, Federal Reserve Bitllet h

were sufficiently detailed to be used to revise nonmember bank data. See Darwin Beck and Joseph Sedransk, "Revision of the Money Stock Measures and Member Bank Reserves and Deposits," Federal Reserve Balletin (February 1974), p. 84. 


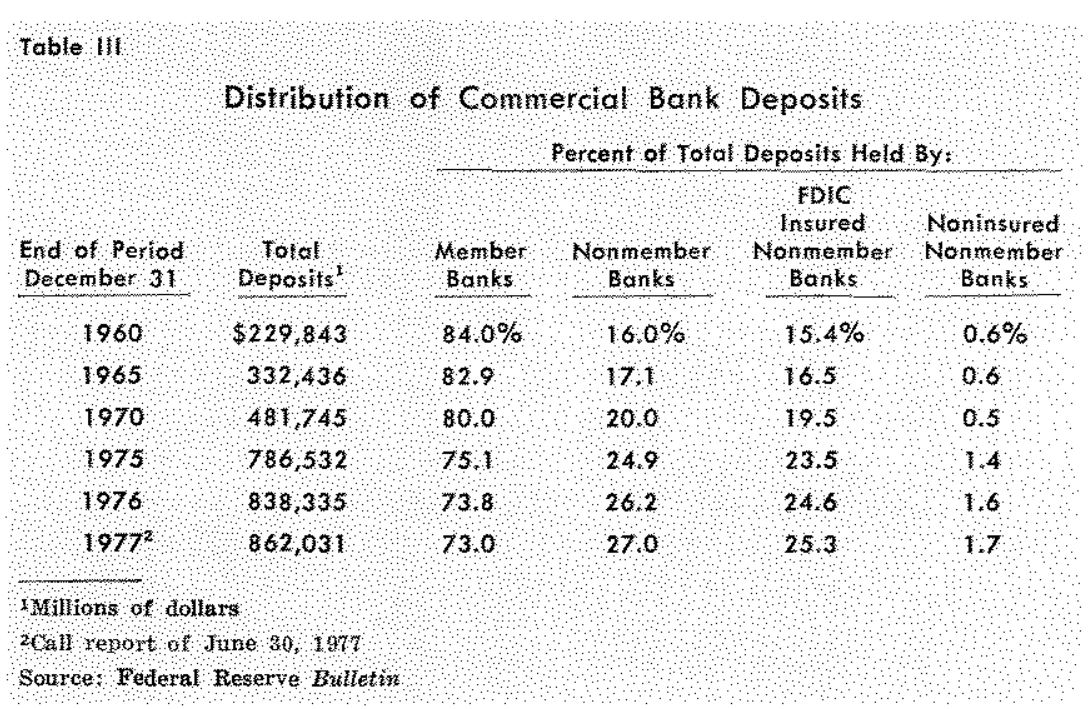

Condition with their respective state banking authorities in accordance with individual state requirements. In general, such call reports are filed twice a year at the end of June and December. Balance sheet data on these noninsured nonmember banks are also collected by the Federal Reserve for use in constructing ML.4

FDIC-insured nonmember banks comprise the majority of nommember banks, both in terms of numbers and in terms of deposits (Tables II and III). There were only 293 noninsured nonmember banks as of June 30,1977 , which accounted for less than 2 percent of the total deposits in the banking system. Thus, the four call reports filed by nonmember banks insured by the FDIC provide the majority of the nonmember bank data used in the construction of M1.

However, since these call reports cover selected balance sheet data only for the one-week period surrounding each call report date, insured nonmember bank data are known only four weeks out of each year." Noninsured nonmember bank data are known even less often - only twice each year. Consequently, weekly data on nonmember bank demand deposits and vault cash must be estimated between call report dates in order to obtain weekly M1 numbers.

\section{ESTIMATION OF NONMEMBER BANK ITEMS}

\section{Deposits}

Between call report dates, weekly data on nonmember bank demand deposits are estimated using

\footnotetext{
4"Improving the Monetary Aggregates," pp. 28-29.

"Prior to March 1976 the call reports filed with the FDIC required balance sheet data for only one day - the date of
}

a subset of generally smaller member banks which prior to November 1972 were classified as "country banks." $\mathrm{De}$ posit data are available with a one- to two-week delay for these smaller member banks. Weekly estimates of nonmember bank demand deposits are obtained by multiplying the smaller member bank demand deposits for a particular week by the estimated ratio of nonmember bank demand deposits to smaller member bank demand deposits. ${ }^{7}$ These estimated ratios are based on the actual ratio of nonmember bank demand deposits to smaller member bank demand deposits as of the call report dates. However, due to the delays in the processing of call report data, there are generally at least three estimates of the same set of weekly nonmember bank deposit data.

For example, consider the estimation of nonmember bank demand deposits for the last week of July. ${ }^{8}$ The estimated ratio of nonmember bank demand deposits to smaller member bank demand deposits for the last week in July is based on a linear interpolation between the ratios of these deposits for the two call report dates surrounding the last week of July (see Figure I). These two call reports are the end-of-June and the end-of-September call reports.

At the time that the July data for member banks become available, however, the September call report has yet to be collected while the data from the

the call report - rather than for the week surrounding the call report date.

6Prior to Novenber 1972, nember banks were classified as either "veserve city" of "country" banks. The "reserve city" category included primarily large banks in financial centers which were subject to higher required reserve ratios on demand deposits than were "country" banks. The "comtry bank" category included all other banks, whether they were in urban on rural areas, regardless of size. See "Recent Regulatory Changes in Reserve Requirements and Check Collection," Federal Reserve Bulletin (July 1972), p. 628 .

TThat is:

Estimated weekly nonmember bank demand

deposits = (Weekly smaller member bank demand deposits)

where the X (Estimated weekly ratio)

ratio = (Nonmember bank denaand deposits)

ratio $=\frac{(\text { Nnaller member bank demand deposits) }}{\text { (Smat }}$

is estimated from the actual ratios as of call report dates.

"Improving the Monetary Aggregates," p. 29.

8Weekly time deposit data for nommember banks, which are used in constructing $M 2$, are estimated in the same way as nonmember bank demand deposits. 


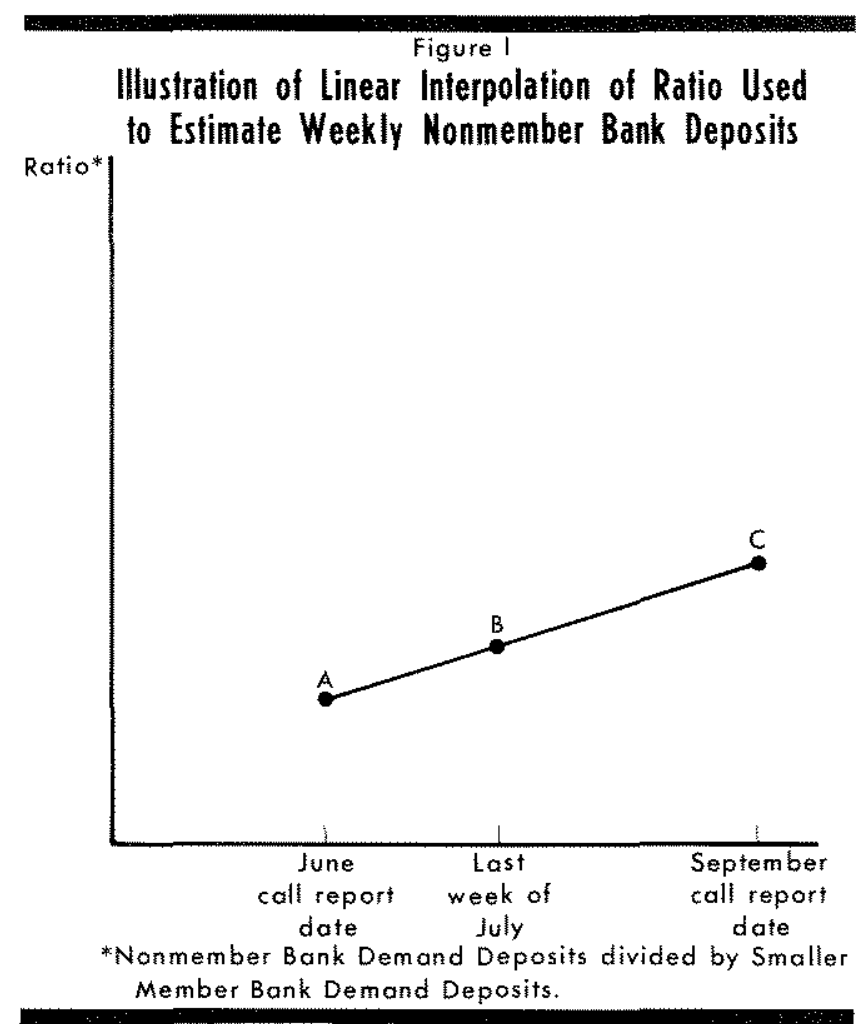

June call report have not been processed. ${ }^{9}$ The delay between the call report date and the release of money stock revisions has generally been four to seven months during the past few years (see Table IV). Consequently, for the June and September call report dates, the ratio of nonmember bank demand deposits to smaller member bank demand deposits is initially estimated by using a regression equation. ${ }^{10}$ The ratio for the last week of July is a linear interpolation between the estimated June and September ratios (see Figure I). This ratio is multiplied by smaller member bank demand deposits for the last week of July to obtain the first estimate of nonmember bank demand deposits for that week.

9Processing the call report data takes a long time for a number of reasons. First, the FDIC lasually forwards the data to the Federal Reserve with a two-month delay. Second, the data must be edited to check for ineorrect filing of reports and omissions of cata. Thirc, the data must be used to re-estimate the ratios used in estimating the weekly data.

${ }_{10}$ The regression equation makes the ratio a function of linear and quadratic time trends and the 3 month Treasury bill rate.

$$
\text { Ratio }=a_{0}+a_{1} t+a_{2} t^{2}+a_{3} \text { TBR }+e
$$
where

$$
t=\text { time }
$$

$T B R=3$-month Treasury bill rate $e=$ error term

Predicted values of the ratio for future call report dates based on this regression equation may be judgmentally adjusted as well. See Beck and Sedransk, "Revision of the Money Stock Measures," pp. 85-86; and "Improving the Monetary Aggregates," p. 29.

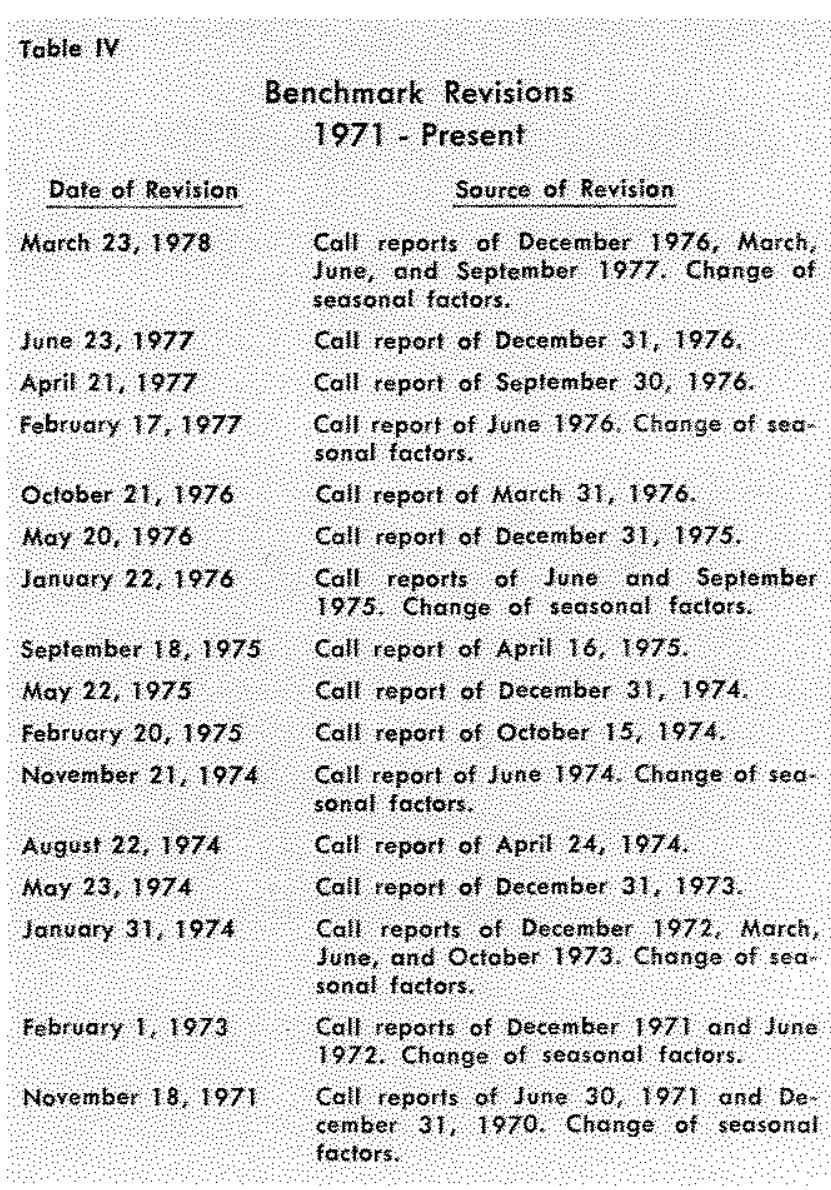

After the June call report data are processed, the actual June ratio replaces the estimated June ratio that is, the data are "benchmarked" to the actual June ratio. In addition, the September ratio is re-estimated to incorporate the effect of the actual June ratio. The ratio for the last week of July is then revised by linearly interpolating between the (new) June and September ratios. This revised ratio is multiplied by the smaller member bank demand deposits for the last week of July to obtain a second estimate of nonmember bank demand deposits.

After the September call report data become available, the actual September ratio is then known and another benchmark revision is made. The ratio for the last week in July is again estimated by linear interpolation between the June and September ratios, from which a third estimate of nonmember bank demand deposits is calculated for the last week of July.

\section{Vault Cash}

Weekly data on nonmember bank vault cash are also estimated between call report dates. In this case, the ratio of nonmember bank vault cash to all mem- 
ber bank vault cash is used to compute weekly estimates of nonmember bank vault cash - by multiplying the vault cash of all member banks for a particular week by this ratio.

Nonmember bank vault cash for the last week of July is also likely to have at least three estimates, although in this case June and September ratios of nonmember bank vault cash to member bank vault cash are not estinated, such as is done for demand deposits. Instead, the actual ratio, as of the latest available call date, is used until the ratios for the surrounding call report dates are known, at which time the ratio for the last week of July is estimated by linear interpolation between the June and September ratios.

In the above example, nonmember bank vault cash for the last week of July would initially be estimated using the ratio of nonmember bank vault cash to member bank vault cash based on the latest available call report. At the time member bank data for the last week of July are available, the latest available call report could be the end-of-March report, although it is more likely to be the end-of-December call report. If the latest available report is the December call report, then the initial estimate of nonmember bank vault cash for the last week of July will be based on the December ratio.

When the March call report becomes available, the March ratio replaces the December ratio, and a second estimate is obtained. The same substitution occurs when the June ratio becomes available. When both the June and September ratios are known, the ratio for the last week of July is estimated by linear interpolation between the two. Consequently, three or four estimates of weekly nonmember bank vault cash could be made.

\section{Difficulties With Revisions}

Given the four- to seven-month delays between the call report dates and the publication of benchmark revisions, the M1 number for the last week of July may be revised even under "normal" reporting conditions as late as eight or nine months after the first estimate is made. In general, the "final" estimate of weekly MI data is made between four and nine months after the week occurs (see Table IV). The delay may be even longer if there are problems in collecting or processing the call reports, such as occurred with the revision announced in March 1978.11

11The delay could also be longer if there are substantial changes in the behavior of deposits or vault cash at noninsured non-
Another source of revisions in the estimates of weekly nonmember bank data involves changes in bank structure between call report dates. Such changes include the formation of new nonmember banks, the Iiquidation of existing nonmember banks, mergers of nommember banks, or the conversion of member banks to nonmember status. Adjustments are made to the weekly estimates of nonmember bank data as these changes in bank structure occur. ${ }^{2}$

The size of benchmark revisions depends on how close the earlier estimates of the nonmember bank components of the money stock are to the later estimates of these data. During the 1970s there has been considerable concern over the size of these benchmark revisions. The level of $\mathrm{Ml}$ changed by more than $\$ 1$ billion as a result of a number of the revisions since 1970 , including an increase of $\$ 2.8$ billion in June 1973.13

A special group (the Bach Committee) studied the problems of bexchmark revisions as part of a larger study of the construction of the monetary aggregates, and recommended in 1976 that changes be made to improve the estimates of nonmember bank data. ${ }^{14}$

To reduce large errors in preliminary estimates of deposits at nonmember banks, we recommend prompt establishment of a weekly reporting sample of large and small nonmember banks and collection of weeklyaverage-of -daily-deposits data from nonmomber banks four times annully in connection with call reports. ${ }^{15}$

As the Bach Committee report was being completed, one of their recommendations - that weekly-averageof-daily-deposits, rather than one-day data, be collected around call report dates - was being implemented by the FDIC starting with the March 1976 call report. Their recommendation that a sample of nonmember banks be established to estimate nonmember bank deposits and vault cash, rather than using member banks, was begun by the FDIC in 1977 . The results of this sample are being evaluated by the Board of Covernors but have not yet been implemented.

member banks. However, these noninsured nonmember banks represent only a very small proportion of deposits (Table III). In addition, separate reports for branches of foreign banks in New York City are available for spring and fall call report dates. Since such branches acoount for the buk of noninasuded nonmember bank deposits, a good estimate of such deposits is generally avalable.

12 Beck and Sedransk, "Revision of the Money Stock Measures," p. 85 .

13 Ibid., pp. 83-86; "Improving the Monetary Aggregates," pp. $28-29$.

14 "Improving the Monetary Aggregates."

15lbid., p. 3. 


\section{BENCHMARK REVISIONS AND MONETARY GROWTH}

An important issue raised by the benchmark revisions of the money stock involves the extent to which these revisions affect monetary growth. With regard to the ranges of monetary growth set by the Federal Open Market Committee (FOMC), the Federal Reserve's principal policymaking body, the issue is whether the revised data substantially change rates of money growth relative to the FOMC's ranges.

Some information concerning this issue can be obtained by examining the impact of the March 1978 benchmark revision on the levels and rates of growth of $\mathrm{M} 1$ and $\mathrm{M} 2$. In so doing, it is useful to distinguish between the short-run and long-run ranges of MI and M2 growth which are set by the FOMC. Each quarter the FOMC sets ranges of growth for M1 and M2 over the next four quarters, taking into consideration such factors as the growth of the economy, the rate of unemployment, and inflation. These one-year ranges are based on the quarterly average of M1 or M2 for the most recent quarter to the quarterly average for Ml or $\mathrm{M} 2$ one year in the future. ${ }^{16}$

In addition, at each of its monthly meetings the FOMC sets two-month ranges for M1 and M2 growth which are expected to be consistent with the one-year ranges. For example, at its June meeting the FOMC specifies an M1 growth range for the two-month JuneJuly period. Then at its July meeting the Committee sets a new range for the July-August period. Although longer-term fluctuations in money growth are more important than short-term fluctuations in terms of effects on output, employment, and prices, these twomonth ranges are guides in the implementation of policy.

When deciding the long" and short-run growth ranges for $M 1$ and $M 2$, the FOMC examines past $M 1$ and $M 2$ growth and projections of future M1 and M2 growth. Significant deviations of M1 or M2 growth from their short-run ranges (if the FOMC's domestic policy directive is a "money market conditions" directive), or from the mid-points of their ranges (if the FOMC's domestic policy directive is a "monetary aggregates" directive), can lead to a change in the FOMC's Federal funds rate objective. ${ }^{17}$ Thus, the issue is whether the benchmark revisions significantly

\footnotetext{
16For a discussion of the FOMC's ranges, see Richard W. Lang,

"The Federal Open Market Committee in 1977," this Review

(March 1978), pp. 2-9.

17 Ibid., pp. 7-9.
}

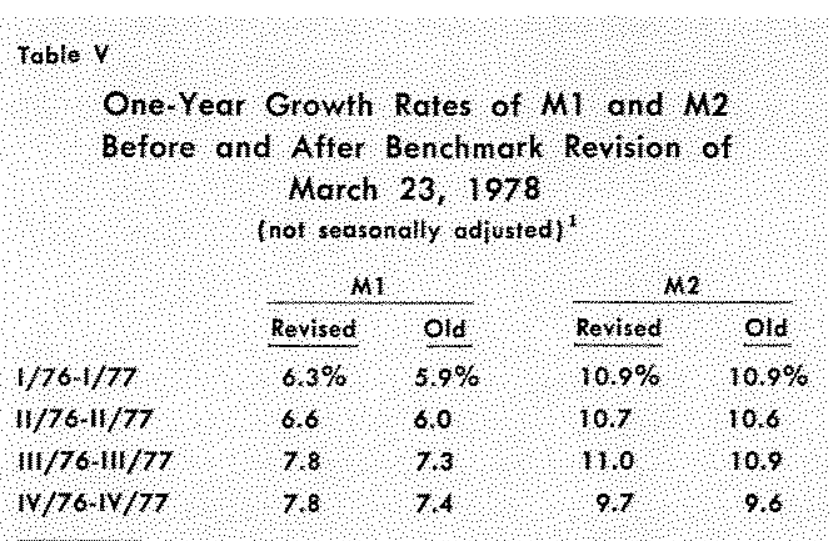

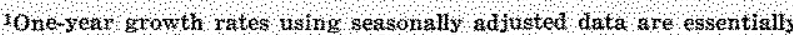
the strat as tho gowth rates strown here.

alter the two-month or one-year growth rates of M1 or $\mathrm{M} 2$ relative to the FOMC's ranges.

\section{One-Year Growth Rates}

For the one-year growth rate of M1 to change by more than one percent, Ml would have to increase (or decrease) relative to the current level of M1 by about $\$ 3.5$ billion. Although such a large benchmark revision is possible, even the March 1978 revision (which incorporated four call reports instead of the usual one or two) changed the level of $\mathrm{M} 1$ at the end of 1977 by only $\$ 1.3$ billion. Since 1970 , only the benchmark revisions for 1973, which were the largest in the history of the series, were large enough to change the growth rate of M1 by one percent. ${ }^{18}$ The most recent benchmark revisions increased the growth rate of M1 from fourth quarter 1976 to fourth quarter 1977 by about four-tenths of one percent, from 7.4 to 7.8 percent (see Table V).

Since the difference between the upper and lower limits of the one-year ranges for $\mathrm{Ml}$ growth has generally been at least 2 percentage points, the probability that a benchmark revision would significantly alter the one-year rate of $M 1$ growth relative to the FOMC's longer-run range is quite small, unless M1 growth were already at the upper or lower limit of its range before the revision.

\section{Two-Month Growth Rates}

Since money growth has often been more volatile over time periods shorter than one year, it is also necessary to examine the effect of benchmark revisions on MI growth for shorter time periods. Table VI gives

18 Beck and Sedransk, "Revisions of the Money Stock Measures," p. 81 . 
the two-month rates of $\mathrm{Ml}$ growth for 1977 using old data and old seasonal factors, revised data and old seasonal factors, and revised data and revised seasonal factors. Calculating growth rates for revised data using old seasonal factors is necessary to separate out the effects of the revision of the seasonal factors for 1977 from the revisions due to benchmark adjustments alone. As can be seen from Table VI, the two-month growth rates of M1 changed by more than one percentage point during the first quarter of 1977. However, in the January-February and February-March periods, neither of the revised growth rates (using old seasonal factors) are outside of the FOMC's short-run range (which was 3 to 7 percent in both periods). In the March-April period, both the old and revised (using old seasonal factors) growth rates are outside of the FOMC's $4 \frac{1}{2}$ to $81 / 2$ percent range. So even though the benchmark revision results in about a 1.5 percentage point increase in the March-April growth rate, the old growth rate was already substantially outside the short-run range.

\begin{tabular}{|c|c|c|c|c|}
\hline & \multicolumn{3}{|c|}{$\begin{array}{l}\text { Two Month Simple Annual } \\
\text { Rates of Change } \\
\text { (seosonally adiusted) }\end{array}$} & \multirow[b]{2}{*}{ Doro os of } \\
\hline & \multirow{2}{*}{$\begin{array}{l}\text { roms } \\
\text { short Run } \\
\text { Banges }\end{array}$} & \multirow{2}{*}{$\begin{array}{l}\text { oldons } \\
\text { soles }\end{array}$} & \multirow{2}{*}{$\begin{array}{l}\text { revised } \\
\text { Mardet } \\
\text { Selo }\end{array}$} & \\
\hline & & & & $\begin{array}{l}\text { Nen } \\
\text { seosenofs }\end{array}$ \\
\hline 1977 & & & & \\
\hline $\mathrm{on}_{s} \mathrm{~F} \mathrm{~B}_{\mathrm{A}}$ & 37 & $31 \%$ & $4, \%$ & $7 \times \%$ \\
\hline $\mathrm{reb}, \mathrm{Man}$ & 37 & 31 & 4.6 & 6.5 \\
\hline $\mathrm{Bar} A \mathrm{Ar}$ & $4 x, 8, y$ & 124 & 139 & 108 \\
\hline$A P \cap A \sigma Y$ & 610 & 101 & 10.6 & 77 \\
\hline $\mathrm{May} / \mathrm{uno}$ & 04 & 26 & 2.8 & 43 \\
\hline one July & $21 / 2-6 / 2$ & 114 & 115 & 95 \\
\hline $\mathrm{Nu} \times \mathrm{Au}$ & $3 / / 2, / / 2$ & 121 & 117 & 91 \\
\hline $\mathrm{Aus}-\mathrm{sept}$ & $0-5$ & 6.6 & 6.0 & 75 \\
\hline $\mathrm{Sepl}, \mathrm{dA}$ & 24 & 9,7 & 9 & 98 \\
\hline$O c k N o v$, & $3-8$ & , 3 & 49 & 56 \\
\hline Nor $\mathrm{Dec}$ & $1 \% 7$ & 31 & 3,0 & 3.8 \\
\hline
\end{tabular}

A comparison of the remaining two-month growth rates for old data (old seasonals) and revised data (old seasonals) for 1977 indicates that in no case did the rate of M1 growth substantially change, nor did the revised growth rate fall inside the FOMC's short-run range if the old growth rate did not (and vice versa). Thus, although shorter-term M1 growth rates may change by larger amounts than one-year growth rates as a result of benchmark revisions, it is still not very likely that such changes will sub- stantially alter these growth rates relative to the FOMC's ranges. This is particularly true since the spread between the upper and lower limits of the shortmun ranges is generally four or more percentage points - much wider than the spread for the longerrun ranges.

One-year and two-month growth rates for M2 in 1977 were also little changed by the recent benchmark revisions (Tables $V$ and VII). Relative to the FOMC's short- or long-run ranges for $M 2$, changes in M2 growth rates due to benchmark revisions are also not likely to be very significant.

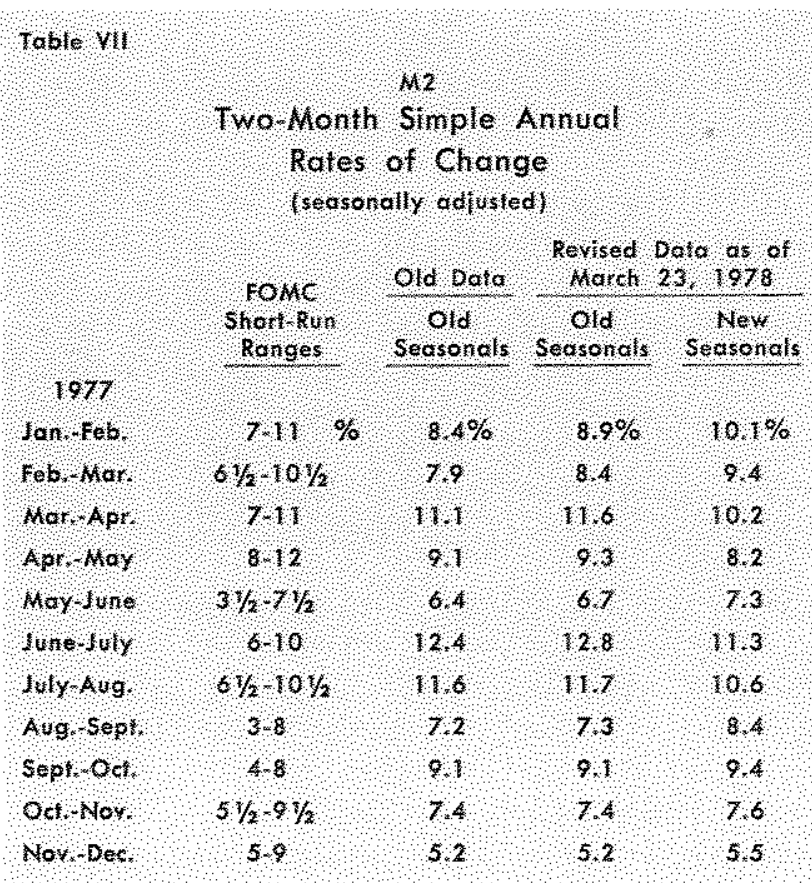

Benchmark revisions seem particularly minor in comparison to revisions of money stock data due to the revision of seasonal adjustment factors (see Tables VI and VII). ${ }^{19}$ For the two-month growth rates of M1, the revisions based on the new seasonal factors for 1977 result in much larger changes in rates of $\mathrm{M} 1$ growth compared to the changes due to the benchmark revisions alone.

\section{BENCHMARK REVISIONS AND FEDERAL RESERVE MEMBERSHTP}

Nonmember bank deposits have comprised an increasing proportion of the monetary aggregates since 1960 (Table III). This has been the result of a num.

\footnotetext{
19Also see the Bach Committee's discussion of revisions of preliminary estimates of the money stock; "Improving the Monetary Aggregates," pp. 25-26.
} 
ber of factors, including more rapid growth of deposits at nonmember banks than at member banks, and the recent decline in membership in the Federal Reserve System (Talle II). Conseguently, estimates of the weekly deposits of nonmember banks have become a larger item in the construction of M1. If Federal Reserve membership continues to decline, will benchmark revisions becone larger? Would these revisions become large enough to affect significantly rates of money growth relative to the FOMC's ranges?

Answers to these questions are not clear-cut, as scenarios can be drawn which give opposite conclusions on the matter. Some of the possible effects of declining Federal Reserve membership can be described, although additional research is necessary to provide conclusive evidence on these questions.

For example, since the size of nonmember bank deposits would increase as Federal Reserve membership declined, the same percentage errors in estimating nommember deposits as have occurred in the past would result in an increase in the size of the benchmark revisions relative to the level of the money stock. Larger revisions would result in larger changes in short- and long-run growth rates of the monetary aggregates relative to the FOMC's ranges.

However, it is possible that the percentage errors in estimating nonmember deposits could either increase or decrease as Federal Reserve membership declines. The present estimates of weekly nonmember deposits depend upon the ratio (as of the call report dates) of nolmember bank deposits to snaller member bank deposits. The present approach implicitly assumes that the relationship between smaller member deposits and nonmember deposits does not change much over time. The larger the changes in this relam tionship from one call report date to the next, the more likely it is that the initial estimates of this ratio will be off the mark, resulting in larger benchmark revisions. Thus, whether or not the relationship between smaller member deposits and nonmember deposits is changed as membership declines becomes an important factor in assessing whether the size of benchmark revisions will increase or decrease.

If the characteristics of banks which drop membership are similar to other nonmember banks characteristics, then the estimates of the ratio would have errors

26For a discussion of the factors affecting the growh of nonmember bank deposits, see John $T$. Rose, "An Analysis of Federal Reserve System Attrition Since 1960" Staff Economic Studies No. 93, Board of Govemors of the Federal Reserve System, 1977. similar to those that have occurred in the past. Alternatively, if the former member banks' characteristics remain the same after they are nonmembers, the estimates of the ratio could, over time, become less subject to errors. The nonmembers' characteristics would become more similar to the members' characteristics in this case, and (after an adjustment period) the ratio of nonmember deposits to member deposits would become more, rather than less, stable.

Alternatively, if the characteristics of former member banks change significantly once they are nonmembers, and if they are not similar to the other nonmembers' characteristics, then the estimates of nonmember data could have even larger errors than the present errors.

The possibility that benchmark revisions will become larger as Federal Reserve membership declines would be reduced by a number of proposals. Suggesm tions have been made to reduce the incentives for member banks to withdraw from the System, or to actually increase the incentives for nonmember banks to join the System. ${ }^{21}$ These include the payment of interest on reserves held at Federal Reserve Banks. Of course, if all nonmember banks joined the Federal Reserve System or if all nonmember banks reported weekly as member banks do now, the problem of estimating nonmember deposits would disappear.

Other proposals have centered on improving the estimates of nonmember bank data in order to reduce the size of benchmark revisions. As mentioned earlier, the Bach Committee concluded that errors in estimates of nonmember components of $\mathrm{Ml}$ could be significantly reduced if a sample of nommember banks would report weekly. This recommendation was based upon an experiment in which the FDIC requested that 573 insured nonmember banks report daily balance sheet data on a weekly basis. This sample of banks included all "large" nonmember banks (177 banks having total deposits in excess of $\$ 100$ million) and groups of smaller nommember banks in various size classes based on their total deposits. ${ }^{29}$

During the period from summer 1974 to spring 1975 , this sample was used to estimate nonmember bank deposits and vault cash. In principle, large nonmember deposits and vault cash were available for each week and did not have to be estimated.23 The weekly deposits and vault cash for smaller nonmember banks

\footnotetext{
21 Ibid., p. 41.

$22^{2}$ "Improving the Monetary Aggregates," pp. 29-30.

23 In fact, not all banks reported on a regular basis,
} 
were estimated using the same technique as illustrated in Figure $I$.

Thus, instead of estimating weekly data for all nonmember banks between call report dates, weekly data for large nonmember banks would be known and only data for small nonmember banks would be estimated. After experimenting with a number of other estimation and sampling techniques, the Bach Committee concluded that the technique described above would significantly improve the construction of the monetary aggregates, and that the costs of increased reporting by nonmember banks compared favorably to the benefits.

After reviewing current procedures, the sample explorations, and various altemative proposals, the Committee concluded that the maccuracies in the estimate of demand deposits of nonmember banks represent a major defect in up-to-date monetary statistics and a significant defect in historical statistics of $\mathrm{MI}$ and that marked improvements are feasible at reasonable costs for both reporting nonmember banks and the Federal agencies involved. ${ }^{24}$

The Bach Committee's proposal would reduce errors in estimating nonmember deposits and vault cash so that growth rates of $\mathrm{M} 1$ and $\mathrm{M} 2$ would be less affected by benchmark revisions. If declining Federal Reserve membership tends to increase the size of benchmark revisions, then such reductions in estimation errors will become more important.

\section{SUMMATI}

Benchmark revisions of the money stock are made usually three or four times each year to incorporate

\footnotetext{
24: Improving the Monetary Aggregates," p. 30.
}

new information on nonmember bank deposits and vault cash. Although these revisions have at times changed the level of the money stock by more than $\$ 2$ billion as of a call report date, only during 1973 have these changes represented as much as a one percent change in the money stock.

The changes in one-year growth rates of M1 and M2 as a result of these benchmark revisions have been quite small, generally changing the growth rates by a few tenths of one percentage point or less. Compared ${ }^{\circ}$ with the two or more percentage point spread in the one-year ranges of M1 and M2 growth set by the FOMC, such changes in $\mathrm{M} 1$ and $\mathrm{M} 2$ growth rates appear to have little effect on monetary growth relative to the FOMC's ranges.

The changes in two-month growth rates of $\mathrm{M} 1$ and M2 as a result of benchmark revisions have been larger, at times changing these short-run growth rates by more than one percentage point. However, the two-month ranges of $\mathrm{M} 1$ and $\mathrm{M} 2$ growth set by the FOMC are much wider than the one-year ranges four percentage points or more. Changes in short-run $\mathrm{M} 1$ and $\mathrm{M} 2$ growth rates also are likely to have little effect on monetary growth relative to the FOMC's ranges.

Whether or not a continuing decline in Federal Reserve membership will increase the size of benchmark revisions remains an open question. In the event that declining membership does increase the errors in estimating nonmember bank components of the money stock, the proposals to reduce the size of the revisions by alternative sampling and estimation techniques, or to encourage increased Federal Reserve membership, will become more important issues.

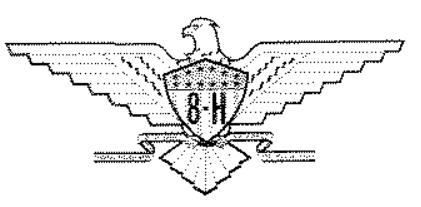

